\title{
Primary Screening of Single Nucleotide Polymorphisms in Human Calreticulin 3 (CALR3)
}

Shinji Irie ${ }^{1}$, Junko Nakamura ${ }^{1}$, Yasushi Miyagawa ${ }^{2}$, Akira Tsujimura $^{2}$, Hidenobu Okuda $^{2}$, Keisuke Yamamoto $^{2}$, Shinichiro Fukuhara ${ }^{2}$, Iwao Yoshioka ${ }^{2}$, Kiuchi Hiroshi ${ }^{2}$, Yasuhiro Matsuoka ${ }^{2}$, Tetsuya $\mathrm{Takao}^{2}$, Norio Nonomura ${ }^{2}$, Masahito Ikawa ${ }^{3}$, Keizo Tokuhiro ${ }^{3}$, Masaru Okabe ${ }^{3}$, Tomomi Shibata ${ }^{4}$, Kyoko Fujimoto ${ }^{4}$, Morimasa $\mathrm{Wada}^{4}$ and Hiromitsu Tanaka ${ }^{4, *}$

${ }^{1} 1$ Life Science Research Laboratory, Toppan Technical Research Institute, Toppan Printing Co., Ltd., 1 Kanda Izumicho, Chiyoda-ku, Tokyo 101-0024, Japan

${ }^{2}$ Department of Urology, Graduate School of Medicine, Osaka University, 1-1 Yamadaoka, Suita, Osaka 565-0871, Japan

${ }^{3}$ Animal Resource Center for Infectious Diseases, Research Institute for Microbial Diseases, Osaka University, 3-1 Yamadaoka, Suita, Osaka 565-0871, Japan

${ }^{4}$ Faculty of Pharmaceutical Sciences, Nagasaki International University, Sasebo, Nagasaki, 859-3298, Japan

\begin{abstract}
Calreticulin 3 (CALR3) is considered a candidate gene in human male infertility because male, but not female, $C A L R 3$-deficient mice are infertile. To investigate the possible association between variations in CALR 3 and impaired spermatogenesis in humans, we screened for mutations in human CALR3 using DNA from 892 infertile male patients and 167 proven-fertile male volunteers. The frequent appearance of several single nucleotide polymorphisms (SNPs), including 742G > T (Asp248Tyr), 976G >A (Asp326Asn), and 1058A>T (Lys353Met), were found in the infertile group by direct sequencing of amplified fragments using the same primers as for polymerase chain reaction. Our results indicate that three major SNPs associated with male infertility exist in the open reading frame of CALR3.
\end{abstract}

Keywords: Sperm, Male Infertility, Genome, SNPs, Fusion.

\section{INTRODUCTION}

Infertility affects approximately $15 \%$ of couples, and in about half of those cases the problem resides with the male [1]. The development of novel fertilization treatments, including in vitro fertilization and intracytoplasmic injection, has made pregnancy possible regardless of the level of activity of the spermatozoa; however, the etiology of malefactor infertility is poorly understood.

Research in mice has revealed several genes that affect fertility [2]. Variation in these genes may cause male infertility [3]. Fertilization involves a series of cellular interactions between the reacted spermatozoa and mature oocyte. Molecules present on the sperm interact with molecules present on the egg [4]. Dysfunction in the genes expressed in sperm may cause infertility. For example, disruption of ADAM3/cyritestin was shown to produce infertility [5]. As these are membrane proteins, molecular chaperones are required for the functional maturation of the proteins in the endoplasmic reticulum (ER). Calmegin (Clgn) -/- male mice were nearly infertile, although spermatogenesis

*Address correspondence to this author at the Faculty of Pharmaceutical Sciences, Nagasaki International University, Sasebo, Nagasaki, 859-3298, Japan; Tel/Fax: +81 956-20-5651; E-mail: h-tanaka@niu.ac.jp was morphologically normal [6]. CLGN contributes to the maturation of FERTILIN $\alpha$ and $\beta$ (also known as ADAM1 and 2), which is important for ADAM3 maturation and the fertilizing ability of sperm [7-9]. Calreticulin 3 (CALR3) is a $\mathrm{Ca}^{2+}$-binding chaperone with a similar expression profile to CLGN, a testis-specific ER chaperone [10]. Carl3 -/- male mice produce normal looking sperm, but migration of the sperm into the oviduct and binding to the zona pellucida are impaired because CALR3 functions in the maturation of ADAM3 [11]. Based on these results, human CALR3 may be involved in sperm-egg interactions either directly or indirectly, and thus be associated with human male infertility.

We examined single nucleotide polymorphisms (SNPs) as a cause of male infertility in an analysis of spermatogenesis-specific genes [12-16]. In the present study, we assessed the prevalence of SNPs in the coding region of CALR3 by the direct sequencing of PCR-amplified DNA from male patients. In total, 1059 DNA samples were analyzed: 892 from infertile patients and 167 from provenfertile volunteers. Thirty-five variations were found in the coding region of CALR3 that induced amino acid substitutions; three other variations were silent. Three SNPs producing amino acid substitutions in exons 6,8 , and 9 were present at a high frequency in a heterozygous state in the infertile patients. Overall, three SNPs $\quad(742 \mathrm{G}>\mathrm{T}$ 
Table 1. The Region Amplified by PCR and Sequeincing Primers for the CALR3 Gene

\begin{tabular}{|c|c|c|c|c|}
\hline \multirow{2}{*}{$\begin{array}{c}\text { Exons } \\
\text { SNPs }\end{array}$} & \multirow{2}{*}{ Location } & \multicolumn{3}{|c|}{ Primers } \\
\cline { 3 - 5 } & & Name & Sequence 5'-3' & Position of 5' \\
\hline \hline EXON 1 & $-63 \sim 91$ & 1 & AGCCGCCACATTCACGCCTGAAGG & -307 \\
\hline EXON 2 & $278 \sim 379$ & $2 \mathrm{r}$ & AACTACCTAGAGAGGTTGCTATGG & 446 \\
\hline \multirow{2}{*}{ EXON 3} & $5560 \sim 5763$ & 3 & TTTGGGAGTAAGGGAAGGACATCG & 5469 \\
\cline { 3 - 5 } & & $4 \mathrm{r}$ & GTCAAAGTCTTAGTCTAAAGATCC & 10729 \\
\hline EXON 4 & $10873 \sim 10967$ & 5.1 & ACCAGCCATGCAGCAATTGTCCAG & 12286 \\
\hline EXON 5 & $12015 \sim 12200$ & $6.1 \mathrm{r}$ & TGGGTGAGAGCAAAACCTAGTCTC & 13242 \\
\hline EXON 6 & $13345 \sim 13452$ & 7 & AGCCTAGGTGACAGAATGAGACCC & 13781 \\
\hline EXON 7 & $13549 \sim 13680$ & $8 \mathrm{r}$ & GTCACCTGAGCTTCATGTATTTCC & 15322 \\
\hline EXON 8 & $15424 \sim 15516$ & 9 & GTTTGAAACATAGATTAAAGTAGC & 17064 \\
\hline EXON 9 & $16856 \sim 17054$ & $10 \mathrm{r}$ & & \\
\hline
\end{tabular}

Table 2. Conditions of PCR for SNPs Analyses

\begin{tabular}{|c|c|c|c|c|c|}
\hline \multirow{2}{*}{ Region } & \multirow{2}{*}{ Primers } & Denatureing & Annealing & Extension Time & \multirow{2}{*}{$\begin{array}{l}\text { Product Size } \\
\text { (bp) }\end{array}$} \\
\hline & & Temp. and Time & Temp. and Time & and Cycle Number & \\
\hline EXON 1,2 & 1 & $98^{\circ} \mathrm{C}, \quad 10 \mathrm{sec}$ & - & $68^{\circ} \mathrm{C}, \quad 60 \mathrm{sec}^{*}$ & 753 \\
\hline \multirow{2}{*}{ EXON 3} & 3 & \multirow{2}{*}{$96^{\circ} \mathrm{C}, \quad 30 \mathrm{sec}$} & \multirow{2}{*}{$60^{\circ} \mathrm{C}, \quad 30 \mathrm{sec}$} & $72^{\circ} \mathrm{C}, 60 \sec ^{* *}$ & \multirow{2}{*}{380} \\
\hline & $4 \mathrm{r}$ & & & 40 cycles & \\
\hline \multirow{2}{*}{ EXON 6,7} & 7 & \multirow{2}{*}{$96^{\circ} \mathrm{C}, \quad 30 \mathrm{sec}$} & \multirow{2}{*}{$60^{\circ} \mathrm{C}, 30 \mathrm{sec}$} & $72^{\circ} \mathrm{C}, \quad 60 \mathrm{sec}^{* *}$ & \multirow{2}{*}{540} \\
\hline & $8 \mathrm{r}$ & & & 40 cycles & \\
\hline \multirow{2}{*}{ EXON 8, 9} & 9 & \multirow{2}{*}{$96^{\circ} \mathrm{C}, \quad 30 \mathrm{sec}$} & \multirow{2}{*}{$60^{\circ} \mathrm{C}, 30 \mathrm{sec}$} & $72^{\circ} \mathrm{C}, \quad 60 \sec ^{* *}$ & \multirow{2}{*}{1,743} \\
\hline & $10 \mathrm{r}$ & & & 40 cycles & \\
\hline
\end{tabular}

Taq polymerases of "KOD Fx (Toyobo, Osaka, Japan) and ** Prime STAR HS (Takara, Siga, Japan) were used for PCR.

[Asp248Tyr], 976G $>\mathrm{A}$ [Asp326Asn], and 1058A $>\mathrm{T}$ [Lys353Met]) were identified as candidates related to human male infertility.

\section{MATERIALS AND METHODS}

\section{Participants}

Japanese subjects with non-obstructive infertility $(\mathrm{N}=$ 892) were assigned to five subgroups according to their sperm count and morphology: azoospermia (28.4\%), severe oligospermia ( $<5$ million cells $/ \mathrm{mL} ; 26.6 \%$ ), asthenospermia $(26.6 \%)$, teratozoospermia $(0.4 \%)$, and normal $(18.0 \%)$. All patients displayed idiopathic infertility and had no history of prior medical conditions, including but not limited to cryptorchidism, recurrent infections, trauma, orchitis, or varicocele. All subjects were identified as having primary idiopathic infertility based on a cytogenetic analysis [17]. The control group consisted of fertile males who had fathered children born at a maternity clinic $(\mathrm{N}=167)$. All of the donors were informed of the purpose of the study and gave permission for their blood to be used for genomic DNA analysis. This study was carried out with the approval of the institutional review board and independent ethics committee of Osaka University.

\section{Identification of SNPs in CALR3 by the Direct Sequencing of Polymerase Chain Reaction (PCR)- Amplified DNA}

DNA samples from the proven-fertile $(\mathrm{N}=167)$ and some of the infertile $(\mathrm{N}=247)$ males were extracted from blood leukocytes. DNA from the remainder of the infertile patients $(\mathrm{N}=645)$ were extracted from the cells in semen samples. Genomic DNA was isolated from blood samples using a protease and phenol extraction. Genomic DNA was isolated from the sperm as follows. Freeze-thawed semen (1 $\mathrm{mL}$ ) was mixed with $1 \mathrm{~mL}$ of phosphate buffered saline (PBS) then centrifuged at $10,000 \mathrm{rpm}$ for $10 \mathrm{~min}$ at $4^{\circ} \mathrm{C}$. The precipitant was used for the extraction of genomic DNA with QuickGene-800 (Fujifilm, Tokyo, Japan) according to the manufacturer's instructions. Sequences corresponding to the region encoded in the nine exons of CALR3 were amplified by PCR using the primers shown in Table $\mathbf{1}$ under the conditions described in Table 2 . The primer sets recognized the introns surrounding each target exon. The sequence containing exons 1 and 2 was amplified using primers 1 and 2r. The sequence containing exon 3 was amplified using primers 3 and $4 r$. The sequence containing exons 4 and 5 was amplified using primers 5.1 and 6.1r. The sequence containing exons 6 and 7 was amplified using primers 7 and 8 r. The sequence containing exons 8 and 9 was amplified 


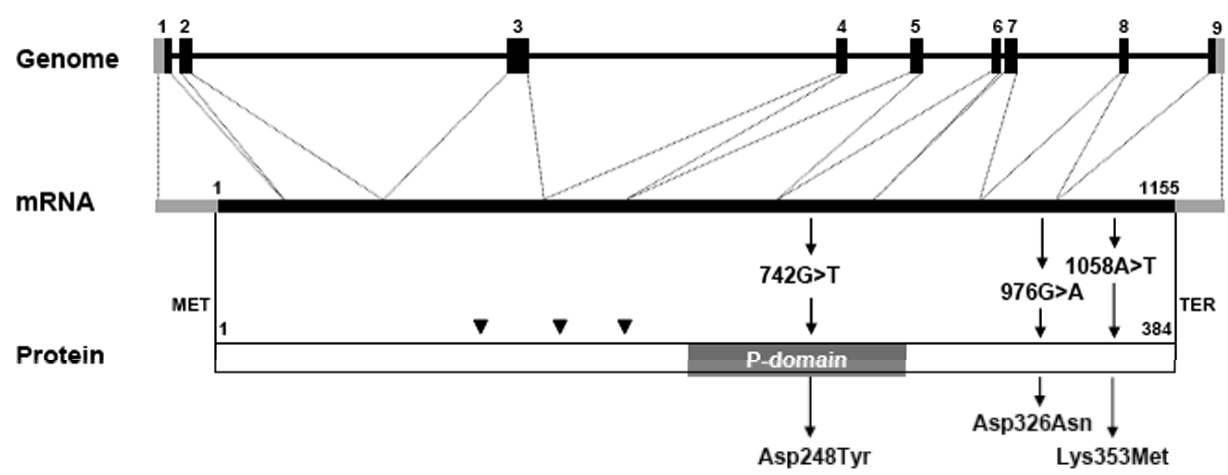

Fig. (1). Schematic view of the 17-kb CALR3 gene (NC_000019.8 [16468003-16450887]), CALR3 mRNA (1288 nucleotides), and CALR3 protein (384 amino acids). Exons 1-9 are depicted as thick boxes; introns are shown as lines. Numbers (upper) indicate the positions of the exons. Three SNPs accumulated in the infertile males are indicated. Each SNP is named based on its position relative to the first nucleotide of the start codon. Numbers (lower) indicate the positions of the amino acids relative to the first methionine (MET). Arrows: conserved cysteine residues, Gray box: P-domain.

using primers 9 and 10r. The PCR-amplified fragments were purified using AMPure ${ }^{\circledR}$ (Agencourt Bioscience Corp., Beverly, MA, USA) and then sequenced using the same PCR primers with a BigDye ${ }^{\circledR}$ Terminator v3.1 Cycle Sequencing Kit (Applied Biosystems, Foster City, CA, USA). The reaction products were purified with BigDye ${ }^{\circledR}$ XTerminator and analyzed using an ABI-PRISM 3730xl Genetic Analyzer (Applied Biosystems). Any subjects with sequence ambiguities were excluded. Screening for variations in the sequences was done using SeqScape ${ }^{\circledR}$ (Applied Biosystems). Those subjects with sequences that were ambiguous in the shape of the wave were removed from the list of SNPs.

\section{Statistical Analysis}

The $\chi^{2}$-test was used to compare the genotype distribution between the infertile subjects and proven-fertile controls. A P-value $<0.05$ was considered to be statistically significant.

\section{RESULTS}

The entire coding sequence of CALR3 (DDBJ/GenBank/EMBL accession number NC_000019.8, 16468003-16450887; CALR3, Fig. 1) and the intronic regions adjacent to each exon were analyzed for sequence variations by direct sequencing. In the first screen, 39 variants were found: one in exon 1 , one in exon 7 , two in exon 2 , four in exon 6 , five in exon 5 , seven in exon 8 , eight in exon 3, and 11 in exon 9 (Table 3). A total of 34 variations were detected only in the infertile patients. The variation-induced amino acid substitutions at $128 \mathrm{~A}>\mathrm{T}$ (Asp43Val), 129C>A (Asp43Glu), 233C >A (Ser78Tyr), 251T $>$ A (Phe84Tyr), 313T $>$ A (Cys105Ser), 328A $>$ T (Ile110Phe), 346G > T (Asp116Tyr), 370G > T (Gly124Stop), 385T $>$ A (Tyr129Asn), 584G $>$ T (Ser195Ile), 586A $>$ T (Ile196Leu), 616A>T (Lys206Stop), 644A> T (Lys215Met), 647A $>\mathrm{T}$ (Asp216Val), 742G $>\mathrm{T}$ (Asp248Tyr), 782A $>\mathrm{T}$ (Tyr261Phe), 783C $>$ A (Tyr261Stop), 820G $>A$ (Val274Ile), 945C $>$ A (Asn315Lys), 946T $>$ A (Phe316Ile), 947T $>$ A (Phe316Tyr), 970T $>$ A (Tyr324Asn), 976G $>$ A (Asp326Asn), 981T >A (Asn327Lys), 1022G >T (Arg341Met), 1023G>T (Arg341Ser), 1034C $>\mathrm{T} \quad$ (Ala345Val), $1046 \mathrm{~A}>\mathrm{T}$ (Lys349Met), $1056 \mathrm{G}>\mathrm{T} \quad$ (Met352Ile), $1058 \mathrm{~A}>\mathrm{T}$ (Lys353Met), $1063 \mathrm{~A}>\mathrm{T} \quad$ (Ala355Ser), $1074 \mathrm{~A}>\mathrm{T}$ (Glu358Asp), 1083A $>\mathrm{T} \quad$ (Glu361Asp), $\quad 1086 \mathrm{G}>\mathrm{T}$
(Glu362Asp ), and 1111C>T (His371Tyr) were either in the major homozygous or heterozygous state; no minor homozygous SNPs were observed. Three different sequence changes, 742G > T (Asp248Thr), 976G >A (Asp326Asn), and $1058 \mathrm{~A}>\mathrm{T}$ (Lys353Met), were increased significantly in the heterozygous state $(\mathrm{P}<0.05)$ in the infertile subjects (Fig. 2). Three SNPs inducing amino acid substitutions, Asp248Thr, Asp326Asn, and Lys353Met, appeared at a frequency $2.2,3.8$, and $6.7 \%$, respectively. SNP 820G $>A$ (Val274Ile), also known as SNP rs12459238, was not significantly increased in the heterozygous and homozygous states in the infertile subjects. Four other SNPs—rs3810201

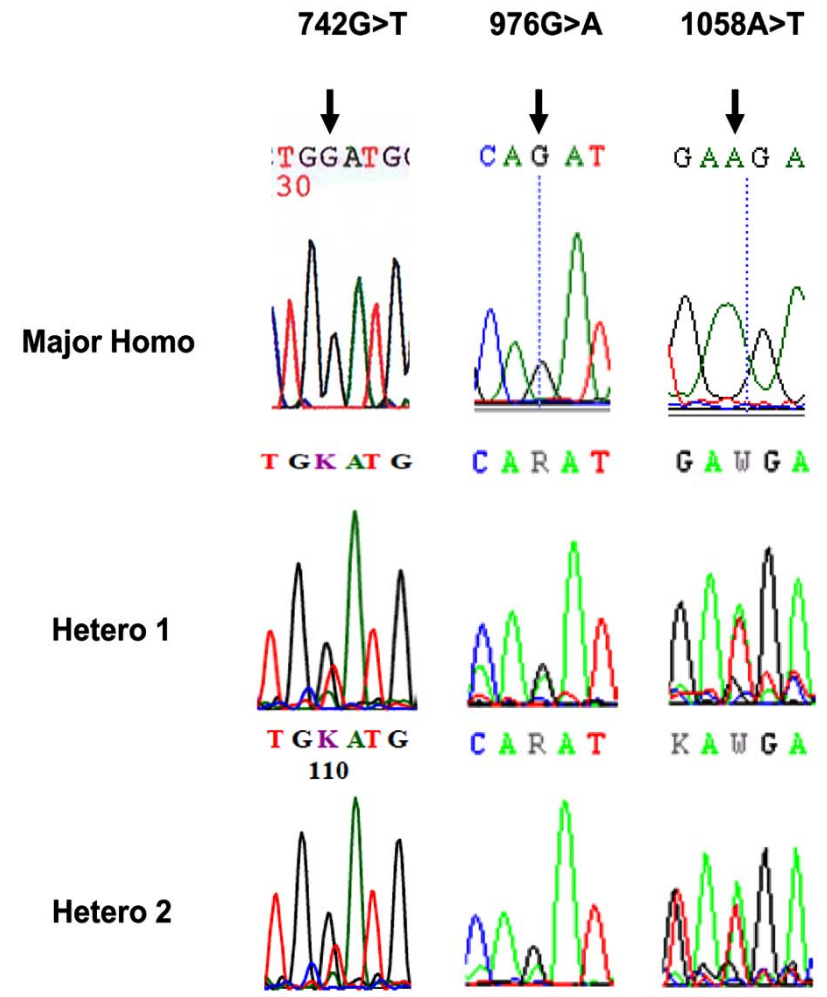

Fig. (2). Detection of SNPs in CALR3. Three nucleic acid positions $(742 \mathrm{G}>\mathrm{T}, 976 \mathrm{G}>\mathrm{A}$, and $1058 \mathrm{~A}>\mathrm{T})$ were distinctly identified as heterozygous genotypes (arrows) upon screening. The translation start site was +1 on the CARL3 cDNA. 
Table 3. The Identified Variants, Positions and Genotypes in Infertile Male and Controls

\begin{tabular}{|c|c|c|c|c|c|c|c|c|c|}
\hline \multirow{3}{*}{$\begin{array}{c}\text { PCR } \\
\text { Primers } \\
1 \times 2 \mathrm{r} \\
\end{array}$} & \multirow{3}{*}{$\begin{array}{c}\text { Exon } \\
1 \\
\end{array}$} & \multicolumn{2}{|c|}{ Position } & \multirow{3}{*}{$\begin{array}{c}\text { Genotype } \\
\text { G/G }\end{array}$} & \multicolumn{4}{|c|}{ Number (\%) of SNP } & \multirow{3}{*}{$\begin{array}{c}\text { Reference } \\
\text { NCBI dbSNP \# } \\
3810201\end{array}$} \\
\hline & & \multirow{2}{*}{$\begin{array}{c}\text { Nucleotide } \\
28\end{array}$} & \multirow{2}{*}{$\begin{array}{c}\text { Amino Acid } \\
\text { Ala10 }\end{array}$} & & \multicolumn{2}{|c|}{ Infertile } & \multicolumn{2}{|c|}{ Proven Fertile } & \\
\hline & & & & & 658 & $(99.7)$ & 165 & $(98.8)$ & \\
\hline & & & Ala10[Ala,Thr] & $\mathrm{G} / \mathrm{A}$ & 1 & $(0.2)$ & 2 & $(1.2)$ & \\
\hline & & & Ala10Thr & $\mathrm{A} / \mathrm{A}$ & 1 & $(0.2)$ & 0 & (0) & \\
\hline & & & & $\mathrm{A} / \mathrm{A}+\mathrm{G} / \mathrm{A}$ & 2 & $(0.3)$ & 2 & $(1.2)$ & \\
\hline & 2 & 128 & Asp43 & $\mathrm{A} / \mathrm{A}$ & 628 & $(99.8)$ & 167 & $(100)$ & \\
\hline & & & Asp43[Asp,Val] & $\mathrm{A} / \mathrm{T}$ & 1 & $(0.2)$ & 0 & (0) & \\
\hline & & 129 & Asp43 & $\mathrm{C} / \mathrm{C}$ & 628 & $(99.8)$ & 167 & $(100)$ & \\
\hline & & & Asp43[Asp,Glu] & $\mathrm{C} / \mathrm{A}$ & 1 & $(0.2)$ & 0 & $(0)$ & \\
\hline \multirow[t]{18}{*}{$3 \times 4 \mathrm{r}$} & 3 & 233 & Ser78 & $\mathrm{C} / \mathrm{C}$ & 817 & $(99.9)$ & 167 & $(100)$ & \\
\hline & & & Ser78[Ser,Tyr $]$ & $\mathrm{C} / \mathrm{A}$ & 1 & $(0.1)$ & 0 & (0) & \\
\hline & & 251 & Phe84 & $\mathrm{T} / \mathrm{T}$ & 821 & (99.9) & 167 & $(100)$ & \\
\hline & & & Phe84[Phe,Tyr] & $\mathrm{T} / \mathrm{A}$ & 1 & $(0.1)$ & 0 & (0) & \\
\hline & & 313 & Cys 105 & $\mathrm{~T} / \mathrm{T}$ & 819 & $(99.9)$ & 167 & $(100)$ & \\
\hline & & & Cys105[Cys,Ser] & $\mathrm{T} / \mathrm{A}$ & 1 & $(0.1)$ & 0 & (0) & \\
\hline & & 328 & Ile110 & $\mathrm{A} / \mathrm{A}$ & 790 & (99.9) & 167 & $(100)$ & \\
\hline & & & Ile110[Ile,Phe] & $\mathrm{A} / \mathrm{T}$ & 1 & $(0.1)$ & 0 & (0) & \\
\hline & & 346 & Asp116 & $\mathrm{G} / \mathrm{G}$ & 742 & $(99.9)$ & 167 & $(100)$ & \\
\hline & & & Asp116[Asp,Tyr] & $\mathrm{G} / \mathrm{T}$ & 1 & $(0.1)$ & 0 & (0) & \\
\hline & & 370 & Gly 124 & $\mathrm{G} / \mathrm{G}$ & 712 & $(99.9)$ & 167 & $(100)$ & \\
\hline & & & Gly $124\left[\right.$ Gly, $\left.{ }^{*}\right]$ & $\mathrm{G} / \mathrm{T}$ & 1 & $(0.1)$ & 0 & (0) & \\
\hline & & 381 & $\mathrm{Gln} 127$ & $\mathrm{~A} / \mathrm{A}$ & 487 & $(69.5)$ & 69 & $(44.5)$ & 3810198 \\
\hline & & & - & G/A & 152 & $(21.7)$ & 60 & $(38.7)$ & \\
\hline & & & - & $\mathrm{G} / \mathrm{G}$ & 62 & (8.8) & 26 & $(16.8)$ & \\
\hline & & & & $\mathrm{G} / \mathrm{G}+\mathrm{A} / \mathrm{A}$ & 214 & $(30.5)$ & 86 & $(55.5)$ & \\
\hline & & 385 & Tyr129 & $\mathrm{T} / \mathrm{T}$ & 696 & $(99.9)$ & 167 & $(100)$ & \\
\hline & & & Tyr65[Tyr,Asn] & $\mathrm{T} / \mathrm{A}$ & 1 & $(0.1)$ & 0 & (0) & \\
\hline \multirow[t]{11}{*}{$5.1 \times 6.1 \mathrm{r}$} & 4 & & & & & & & & \\
\hline & 5 & 584 & Ser195 & $\mathrm{G} / \mathrm{G}$ & 248 & $(99.6)$ & 108 & $(100)$ & \\
\hline & & & Ser195[Ser,Ile] & $\mathrm{G} / \mathrm{T}$ & 1 & $(0.4)$ & 0 & (0) & \\
\hline & & 586 & Ile196 & $\mathrm{A} / \mathrm{A}$ & 245 & $(98.8)$ & 108 & $(100)$ & \\
\hline & & & Ile196[Ile,Leu] & $\mathrm{A} / \mathrm{T}$ & 3 & (1.2) & 0 & (0) & \\
\hline & & 616 & Lys206 & $\mathrm{A} / \mathrm{A}$ & 242 & $(98.4)$ & 108 & $(100)$ & \\
\hline & & & Lys206[Lys, $\left.{ }^{*}\right]$ & $\mathrm{A} / \mathrm{T}$ & 4 & (1.6) & 0 & (0) & \\
\hline & & 644 & Lys 215 & $\mathrm{~A} / \mathrm{A}$ & 241 & $(99.2)$ & 108 & $(100)$ & \\
\hline & & & Lys215[Lys,Met] & $\mathrm{A} / \mathrm{T}$ & 2 & $(0.8)$ & 0 & (0) & \\
\hline & & 647 & Asp216 & $\mathrm{A} / \mathrm{A}$ & 238 & $(99.2)$ & 108 & $(100)$ & \\
\hline & & & Asp216[Asp,Val] & $\mathrm{A} / \mathrm{T}$ & 2 & $(0.8)$ & 0 & (0) & \\
\hline \multirow[t]{4}{*}{$7 \times 8 r$} & 6 & 702 & 234Asp & $\mathrm{C} / \mathrm{C}$ & 588 & (91.6) & 110 & $(88.7)$ & 10403020 \\
\hline & & & - & $\mathrm{C} / \mathrm{T}$ & 47 & (7.3) & 11 & (8.9) & \\
\hline & & & - & $\mathrm{T} / \mathrm{T}$ & 7 & (1.1) & 3 & $(0.4)$ & \\
\hline & & & & $\mathrm{T} / \mathrm{T}+\mathrm{C} / \mathrm{T}$ & 54 & (8.4) & 14 & (9) & \\
\hline
\end{tabular}


Table 3. cont...

\begin{tabular}{|c|c|c|c|c|c|c|c|c|c|}
\hline & & 742 & Asp248 & $\mathrm{G} / \mathrm{G}$ & 675 & $(97.8)$ & 270 & $(100)$ & \\
\hline & & 782 & Tyr261 & $\mathrm{A} / \mathrm{A}$ & 692 & $(99.9)$ & 124 & $(100)$ & \\
\hline & & 783 & Tyr261 & $\mathrm{C} / \mathrm{C}$ & 692 & $(99.9)$ & 124 & $(100)$ & \\
\hline & & & Tyr261[Tyr,*] & $\mathrm{C} / \mathrm{A}$ & 1 & $(0.1)$ & 0 & $(0)$ & \\
\hline & & & Val274[Val,Ile] & $\mathrm{G} / \mathrm{A}$ & 18 & (2.6) & 5 & (3.9) & \\
\hline \multirow[t]{29}{*}{$9 \times 10 \mathrm{r}$} & 8 & 945 & Asn315 & $\mathrm{C} / \mathrm{C}$ & 151 & $(99.3)$ & 151 & $(100)$ & \\
\hline & & & Asn315[Asn,Lys] & $\mathrm{C} / \mathrm{A}$ & 1 & $(0.7)$ & 0 & (0) & \\
\hline & & 946 & Phe316 & $\mathrm{T} / \mathrm{T}$ & 153 & $(99.4)$ & 151 & $(100)$ & \\
\hline & & & Phe316[Phe,Ile] & $\mathrm{T} / \mathrm{A}$ & 1 & $(0.6)$ & 0 & (0) & \\
\hline & & & Tyr324[Tyr,Asn] & $\mathrm{T} / \mathrm{A}$ & 1 & $(0.6)$ & 0 & (0) & \\
\hline & & 972 & Tyr324 & $\mathrm{C} / \mathrm{C}$ & 17 & $(10.8)$ & 40 & $(26.5)$ & 9305079 \\
\hline & & & - & $\mathrm{C} / \mathrm{T}$ & 37 & $(23.4)$ & 42 & $(27.8)$ & \\
\hline & & & - & $\mathrm{T} / \mathrm{T}$ & 104 & $(65.8)$ & 69 & $(45.7)$ & \\
\hline & & 976 & Asp326 & $\mathrm{G} / \mathrm{G}$ & 154 & $(96.3)$ & 151 & $(100)$ & \\
\hline & & & Asp326[Asp,Asn] & $\mathrm{G} / \mathrm{A}$ & 6 & $(3.7)$ & 0 & $(0)$ & \\
\hline & & 981 & Asn327 & $\mathrm{T} / \mathrm{T}$ & 172 & $(99.4)$ & 151 & $(100)$ & \\
\hline & & & Asn327[Asn,Lys] & $\mathrm{T} / \mathrm{A}$ & 1 & $(0.6)$ & 0 & (0) & \\
\hline & 9 & 1022 & $\operatorname{Arg} 341$ & G/G & 420 & $(99.8)$ & 151 & $(100)$ & \\
\hline & & & Lys349[Lys,Met] & $\mathrm{A} / \mathrm{T}$ & 1 & $(0.2)$ & 0 & (0) & \\
\hline & & 1056 & M352 & G/G & 399 & $(99.5)$ & 151 & $(100)$ & \\
\hline & & & Met352[Met,Ile] & $\mathrm{G} / \mathrm{T}$ & 2 & $(0.5)$ & 0 & (0) & \\
\hline & & 1058 & Lys353 & $\mathrm{A} / \mathrm{A}$ & 374 & (93.3) & 151 & $(100)$ & \\
\hline & & & Lys353[Lys,Met] & $\mathrm{A} / \mathrm{T}$ & 27 & $(6.7)$ & 0 & $(0)$ & \\
\hline & & 1063 & Ala335 & $\mathrm{G} / \mathrm{G}$ & 395 & $(99.7)$ & 151 & $(100)$ & \\
\hline & & & Ala335[Ala,Ser] & $\mathrm{G} / \mathrm{T}$ & 1 & $(0.3)$ & 0 & (0) & \\
\hline & & 1074 & Glu358 & $\mathrm{A} / \mathrm{A}$ & 387 & $(99.7)$ & 151 & $(100)$ & \\
\hline & & & Glu358[Glu,Asp] & $\mathrm{A} / \mathrm{T}$ & 1 & $(0.3)$ & 0 & (0) & \\
\hline & & 1083 & Glu361 & $\mathrm{A} / \mathrm{A}$ & 371 & $(99.7)$ & 151 & $(100)$ & \\
\hline & & & Glu361[Glu,Asp] & $\mathrm{A} / \mathrm{T}$ & 1 & $(0.3)$ & 0 & (0) & \\
\hline & & 1086 & Glu362 & $\mathrm{G} / \mathrm{G}$ & 368 & (99.7) & 150 & (99.3) & \\
\hline & & & - & $\mathrm{G} / \mathrm{A}$ & 0 & $(0)$ & 1 & $(0.7)$ & \\
\hline & & & Glu362[Glu,Asp] & $\mathrm{G} / \mathrm{T}$ & 1 & $(0.3)$ & 0 & (0) & \\
\hline & & 1111 & His371 & $\mathrm{C} / \mathrm{C}$ & 313 & $(99.7)$ & 151 & $(100)$ & \\
\hline & & & His371[His,Tyr] & $\mathrm{C} / \mathrm{T}$ & 1 & $(0.3)$ & 0 & (0) & \\
\hline
\end{tabular}

The translation start site was +1 on Calr 3 cDNA.

The whole population could not been fully determined due to the condition of some samples.

* Asterisks indicate the nonsense codon. 
(28G $>A$ (Ala10Thr)) in exon 1, rs3810198 (381A $>\mathrm{G}$ $(\mathrm{Gln} 27))$ in exon 3, rs10403020 (702C $>\mathrm{T}(\mathrm{Asp} 234))$ in exon 6 , and rs9305079 (972C $>\mathrm{T}$ (Tyr324)) in exon 8-appear not to be related to infertility. Overall, there was no correlation between the frequency of these SNPs and the type of infertility or sample source.

\section{DISCUSSION}

CALR3 is involved in sperm-egg interactions [11], and thus may be associated with human male infertility. Male infertile patients may have mutations in CALR3. In this study, we found several differences in genotype distribution causing amino acid substitutions between the infertile subjects and fertile controls. The high frequency of appearance of the SNPs 742G>T (Asp248Tyr), 976G $>$ A (Asp326Asn), and 1058A $>$ T (Lys353Met) suggests that they are candidate SNPs causing infertility.

CALR3-deficient mice show idiopathic infertility with normal sperm formation [11]. Polymorphisms in CALR3 may cause human infertility based on differences in species and genetic background. Polymorphism $742 \mathrm{G}>\mathrm{A}$ is located in the coding region of the P-domain. The amino acid sequence of the CALR3 P-domain is not highly homologous to the consensus P-domain [10]. The P-domain of CALR3 is proline-rich. This region of the protein binds $\mathrm{Ca}^{2+}$ with high affinity and may be critical for the protein-specific chaperone activity of CALR3 [11]. Polymorphisms 976G>A and $1058 \mathrm{~A}>\mathrm{T}$ were found in the acidic $\mathrm{C}$-terminal domain, which binds multiple $\mathrm{Ca}^{2+}$ ions with low affinity. Although the region lacks the consensus amino acid sequence in human and mouse CALR and CALR3, our results indicate that the acidic C-terminal domain may be important for the activity of CALR3. There was no correlation between the frequency of the SNPs and the type of infertility in this study, but such an association may be found by analyzing a greater number of subjects. Until now, data have been lacking regarding the relationship between $C A L R 3$ and male infertility. This is the first analysis of mutations in CALR3 in males with non-obstructive azoospermia. Our findings indicate that $C A L R 3$ may be associated with male infertility. Further investigation and functional studies of these variants are necessary to confirm whether the mutation of CALR3 causes infertility in males.

\section{ACKNOWLEDGMENTS}

We thank Ms. Mayumi Kato for their assistance in analyzing the sequences of the human DNA samples.

\section{CONFLICT OF INTEREST}

None Declared.

\section{REFERENCES}

[1] Skakkebaek NE, Jørgensen N, Main KM, et al. Is human fecundity declining? Int J Androl 2006; 29: 2-11.

[2] Matzuk MM, Lamb DJ. Genetic dissection of mammalian fertility pathways. Nat Cell Biol 2002; 4 (Suppl) s41-9.

[3] Tanaka H, Hirose M, Tokuhiro K, et al. Molecular biological features of male germ cell differentiation. Reprod Med Biol 2007; 6: $1-9$.

[4] Rubinstein E, Ziyyat A, Wolf JP, Le Naour F, Boucheix C. The molecular players of sperm-egg fusion in mammals. Semin Cell Dev Biol 2006; 17: 254-63.

[5] Shamsadin R, Adham IM, Nayernia K, Heinlein UAO, Oberwinkler H, Engel W. Male mice deficient for germ-cell cyritestin are infertile. Biol Reprod 1999; 61: 1445-51.

[6] Ikawa M, Wada I, Kominami K, et al. The putative chaperone calmegin is required for sperm fertility. Nature 1997; 387: 607-11.

[7] Ikawa M, Nakanishi T, Yamada S, et al. Calmegin is required for fertilin alpha/beta heterodimerization and sperm fertility. Dev Biol 2001; 240: 254-61.

[8] Yamaguchi R, Yamagata K, Ikawa M, Moss SB, Okabe M. Aberrant distribution of ADAM3 in sperm from both angiotensinconverting enzyme (Ace)- and calmegin (Clgn)-deficient mice. Biol Reprod 2006; 75:760-6.

[9] Yamaguchi R, Muro Y, Isotani A, et al. Disruption of ADAM3 impairs the migration of sperm into oviduct in mouse. Biol Reprod 2009; 81: 142-6.

[10] Persson S, Rosenquist M, Sommarin M. Identification of a novel calreticulin isoform (Crt2) in human and mouse. Gene 2002; 297 : 151-8.

[11] Ikawa M, Tokuhiro K, Yamaguchi R, et al. Calsperin is a testisspecific chaperone required for sperm fertility. J Biol Chem 2011; 286: 5639-46.

[12] Nishimune $\mathrm{Y}$, Tanaka H. Infertility caused by polymorphisms or mutations in spermatogenesis-specific genes. J Androl 2006; 27 : 326-34.

[13] Tanaka H, Hirose M, Tokuhiro K, et al. Single nucleotide polymorphisms: discovery of the genetic causes of male infertility. Soc Rep Fert Suppl 2007; 65: 531-4.

[14] Tokuhiro K, Hirose M, Miyagawa Y, et al. Meichroacidin containing the membrane occupation and recognition nexus motif is essential for spermatozoa morphogenesis. J Biol Chem 2008; 283: $19039-48$

[15] Irie S, Tsujimura A, Miyagawa $\mathrm{Y}$, et al. Single nucleotide polymorphisms of the PRDM9 (MEISETZ) gene in patients with non-obstructive azoospermia. J Androl 2009; 30: 426-31.

[16] Irie S, Nakamura J, Tsujimura A, Miyagawa Y, Tanaka H. Single nucleotide polymorphisms of the IZUMO gene in male intertile patients. Nagasaki Int Univ Review 2010; 10: 209-18.

[17] World Health Organization. WHO Laboratory manual for the examination of human semen and sperm-cervical mucus interaction. $4^{\text {th }}$ ed. Cambridge: Cambridge University Press 1999. 